\title{
Genetic polymorphisms in $\beta$-defensin II gene in Amazon sheep from Brazil
}

\author{
B.B. Souza', E.M. Barbosa ${ }^{2}$, J.S.N. Azevedo ${ }^{3}$, J.E.G. Campelo ${ }^{4}$, \\ L.F.S. Rodrigues ${ }^{3}$, L.M.L. Pinheiro ${ }^{5}$, S.C.B Silva ${ }^{7}$, A.S. Schierholt ${ }^{3}$, P.H. Souza ${ }^{3}$, \\ E.C. Gonçalves ${ }^{5}$ and E. Silva Filho ${ }^{3}$ \\ ${ }^{1}$ Curso de Zootecnia, Universidade Federal Rural da Amazônia, Belém, PA, Brasil \\ ${ }^{2}$ Curso de Pós-graduação em Ciência Animal da Universidade Federal do Pará, \\ Belém, PA, Brasil \\ ${ }^{3}$ Centro de Pesquisa de Caprinos e Ovinos do Pará, \\ Universidade Federal Rural da Amazônia, Belém, PA, Brasil \\ ${ }^{4}$ Departamento de Zootecnia, Universidade Federal do Piauí, Teresina, PI, Brasil \\ ${ }^{5}$ Departamento de Ciências Naturais, Universidade Federal do Pará, \\ Breves, PA, Brasil \\ ${ }^{6}$ Instituto de Ciências Biológicas, Universidade Federal do Pará, Belém, PA, Brasil \\ ${ }^{7}$ Departamento de Medicina Veterinária, Universidade Estadual de Santa Cruz, \\ Ilhéus, BA, Brasil
}

Corresponding author: E. Silva Filho

E-mail: silva.filho@ufra.edu.br

Genet. Mol. Res. 14 (4): 12805-12810 (2015)

Received May 14, 2015

Accepted August 20, 2015

Published October 19, 2015

DOI http://dx.doi.org/10.4238/2015.October.19.24

ABSTRACT. The northern region of Brazil produces a large number of sheep, with Pará being the largest sheep breeding state in the region. In the Amazon region, livestock production is a challenge due to the high diversity of pathogens affecting humans and animals. Defensins are antimicrobial peptides acting as a first barrier against micro-organisms and present high variation in different organisms. The objective of this study was to detect polymorphisms in exon II in $\beta$-defensin II in Amazon sheep. The gene was amplified by PCR from DNA extracted from 47 sheep blood samples from the Santa Inês breed. Products were sequenced, aligned and analyzed. 
Three single nucleotide polymorphism (SNP) positions were observed with transition substitutions $(A \leftrightarrow G)$ at positions 1643,1659 , and 1750 . The 1643 and 1750 SNPs showed a low variability and significant deviations from Hardy-Weinberg equilibrium (HWE) $(P<0.05)$ meanwhile the SNP 1659 showed moderate absence of genetic variability and deviation from HWE $(P>0.05)$. Polymorphisms at 1643 and 1659 were predicted to modify amino acids in the peptide chain (isoleucine to valine and arginine to lysine, respectively) with no effects on protein function. Results from this study suggest that SNPs are important markers for $\beta$-defensin II efficiency studies on the immune system of sheep in the Brazilian Amazon.

Key words: Sheep beta defensin-2; Innate immunity; Sheep; Single nucleotide polymorphism; Antimicrobial peptides

\section{INTRODUCTION}

The Brazilian north is made up entirely of the Amazon biome, which is a challenge for livestock production. The sheep industry is one of the main activities of the Amazon agro-ecological system, with the production of meat, milk and other animal derivatives (Pereira et al., 2008). The north has approximately 627,700 head of sheep, or $3.6 \%$ of the national effective, while the state of Pará has the largest effective of the northern region, with approximately 213,000 sheep (33.9\% of the region) (IBGE, 2011).

In northern Brazil, production of sheep and other domestic animals is challenged by a wide diversity of microorganism pathogens and vectors, as well as hematophagous arthropods and wild vertebrates enabling the maintenance of these microorganisms, responsible for diseases of humans and livestock, including sheep, goats, cattle, horses, and buffalo (Casseb et al., 2013).

Defensins are a family of small peptides involved in innate immune mechanisms, and act against bacteria, viruses, and fungi by their antimicrobial and cytotoxic activities (Brogden et al., 2003). They are considered antimicrobial peptides (AMPs) and according to structure, size and pattern of disulfide bonds, can be classified into $\alpha-, \beta$-, and $\theta$-defensins (Kaiser and Diamond, 2000; Selted and Ouellette, 2005).

Two types of $\beta$-defensins have been identified in sheep: sheep $\beta$-defensin (SBD) -1 and -2 (Huttner et al., 1998a, 1998b). The two share $87 \%$ nucleotide sequence identity, and $78 \%$ amino acid identity (Bagnicka et al., 2010). In sheep, SBD-2, the gene encoding SBD-2, is located on chromosome 26 and consists of two exons and an intron. It comprises approximately $1500 \mathrm{bp}$, with exon I consisting of $58 \mathrm{bp}$ and exon II, $296 \mathrm{bp}$. Exon II contains the information required for synthesis of pro-peptide and the mature peptide comprised of 64 aa (Huttner et al, 1998b).

In a study evaluating polymorphisms in SBD-2 in Italian sheep, four SNPs were found: one in exon I, and three in exon II (Monteleone et al., 2009). Monteleone et al. (2011) conducted a study of Italian sheep and found five SNPs: one in exon I; and four in exon II, some of which were found to cause changes in the SBD-2 amino acid chain. The aim of the current study was to analyze the sequence of nucleotides of exon II and part of the 3' untranslated region (3'-UTR) of SBD-2 in a flock of sheep in the Amazon (Pará, Brazil), in order to identify possible nonsynonymous polymorphisms in this gene. 


\section{MATERIAL AND METHODS}

\section{Sample and laboratory proceedings}

Forty-seven unrelated Santa Inês breed sheep (40 males and 7 females) were obtained from the Universidade Federal Rural da Amazônia in Belém, Pará. Blood ( $3 \mathrm{~mL}$ ) was collected from the jugular vein of each sheep using Vacutainer (Weihi Hongyu Medical Devices Co Ltd. Weihai, Shagond, China). Blood DNA extraction was performed using a phenol:chloroform:isoamyl alcohol (25:24:1) method as described by Sambrook et al. (1989). Polymerase chain reaction (PCR) was performed on DNA samples to isolate and amplify a fragment length of $392 \mathrm{bp}$, comprising the exon II and part of the 3'-UTR of SBD-2. Primers used for PCR were those described by Monteleone et al. (2009) Amplifications were carried out in a final volume of $25 \mu \mathrm{L}$, containing 1X STR 10X buffer; $3 \mathrm{mM} \mathrm{MgCl}$; $1.2 \mathrm{mM}$ of each dNTP; 5 pmol primer; $1 \mathrm{U}$ Taq DNA polymerase (500 units, Invitrogen, Life Technology, Carlsbad, CA, USA); and 50-100 ng genomic DNA. The initial desnaturation temperature was $94^{\circ} \mathrm{C}$ for $5 \mathrm{~min}$, followed by 30 cycles of $94^{\circ} \mathrm{C}$ for $1 \mathrm{~min}, 60^{\circ} \mathrm{C}$ for $45 \mathrm{~s}$, and $72^{\circ} \mathrm{C}$ for $1 \mathrm{~min}$. Reactions were maintained at $72^{\circ} \mathrm{C}$ for a final extension of $10 \mathrm{~min}$. A 2720 Thermal Cycler was used (Applied Biosystems ${ }^{\circledR} 2720$ Thermal Cycler, Life Technology, Carlslad, CA, USA). Amplification products were visualized on a $1.5 \%$ agarose $(w / v)$ gel containing Gelred (Biotium, Hayward, California, USA), then purified with the enzyme Illustra ExoProStar 1-Step following the manufacturer recommendations (GE Healthcare, London, UK). Purified products were sequenced using a Big Dye kit (Life Technology, Carlslad, CA, USA) in an automatic DNA sequencer ABI 3500 XL (Applied Biosystems ${ }^{\text {TM }}$ Life Technology Carlslad, CA, USA).

\section{Analysis of sequences and statistics}

Sequences were edited and aligned using the Bioedit program (Hall, 1999) and a reference sequence submitted in Genebank as NCBI reference sequence No. U75251.1. The program POPGENE 1.32 (Yeh et al., 1999) was used to determine allele and genotype frequencies and the Shannon index. The program GENEPOP (Raymond and Rousset, 1995) was used to determine observed and expected homo- and heterozygosities, as well as deviations from Hardy-Weinberg equilibrium (HWE) in the presence of random association of genotypes using the Markov chain method and inbreeding coefficient (Fis) in the examined herd.

Protein analysis through evolutionary relationships (PANTHER) software was used to estimate the likelihood of nonsynonymous coding polymorphisms causing functional impacts on protein, through the substitution position-specific evolutionary conservation (SCORE subPSEC) and a probability $\left(\mathrm{P}_{\text {deleterius }}\right)$, based on alignments of evolutionarily related proteins (Thomas et al., 2003). Sorting intolerance from tolerance (SIFT) software was used to predict effects on protein function for aa substitutions analyzed by SCORE ( $\mathrm{Ng}$ and Henikoff, 2003).

\section{RESULTS}

Polymerase chain reaction products from each animal were sequenced in forward and reverse directions. Following sequence editing and alignment, three polymorphic positions were observed at positions 1643 and 1659 in exon II, and 1750 in the 3'-UTR region. All substitutions were transition type $(A \leftrightarrow G)$, with position 1643 being a transition from $A$ to $G$, and 1659 and 1750 from $G$ to $A$. Based on wild-type sequence, substitution of nitrogenous base from $A$ to $G$ at position 
1643 changed the 37 th aa from isoleucine $(\mathrm{I})$ to valine $(\mathrm{V})$, and the $\mathrm{G}$ to $A$ substitution at position 1659 changed the $42 \mathrm{nd}$ aa from arginine $(\mathrm{R})$ to lysine (K) (Figure 1).

Based on sequence homology and physical properties, these aa changes were not predicted to affect protein function. Prediction performances to aa substitutions were -1.66863 $\left(P_{\text {deleterius }}=0.20893\right)$ in the 37 th position, and $-1.81977\left(P_{\text {deleterius }}=0.23501\right)$ in the 42 nd position. At the 37 th position, the substitution I to $\mathrm{V}$ was predicted to be tolerated, with a score of 0.43 . The substitution at the 42 nd position was also tolerated, with a score of 0.62 .

The frequency of the wild type allele $A$ at position 1643 was higher $(0.957)$ than that of the mutant allele $G(0.043)$. At position 1659 , the frequency of the wild type allele $G$ was higher $(0.564)$ than that of the mutant allele $A(0.436)$, and for position 1750 in the $3^{\prime}-$ UTR region, the frequency of the wild type $G$ was higher (0.915) than that of the mutant allele A (0.085) (Table 1). All possible genotypes for each SNP were detected, with AA the most frequent genotype at position $1643(0.936)$; AG most frequent at position 1659 (0.532); and GG most frequent at position 1750 (0.872) (Table 1).

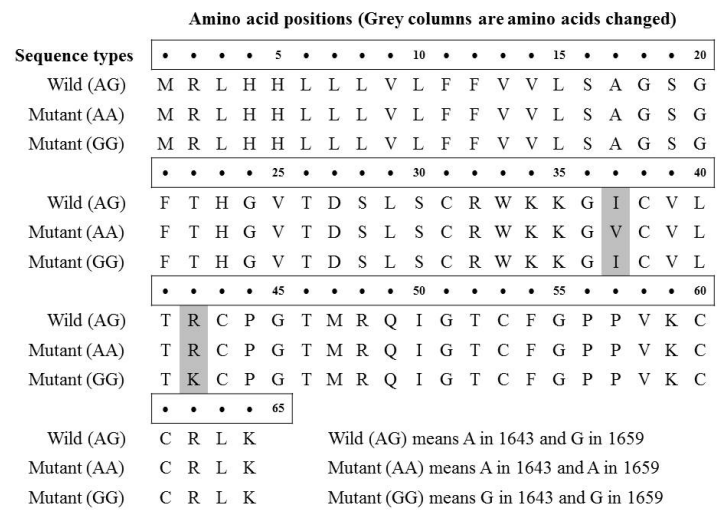

Figure 1. Alignment of amino acid sequences of SBD-2 in sheep due to SNPs at nucleotide positions 1643 and 1659.

\begin{tabular}{|c|c|c|c|c|c|c|c|c|}
\hline SNP position (substitution) & Genotype* $^{*}$ & Allele $^{*}$ & $H_{0}$ & $H_{\circ}$ & $H_{\mathrm{E}}$ & $\mathrm{SI}$ & $F_{\text {IS }}$ & P-HW \\
\hline $1643(A \rightarrow G)$ & $\begin{array}{l}\text { AA }(0.936) \\
\text { AG }(0.043) \\
\text { GG }(0.021)\end{array}$ & $\begin{array}{l}\mathrm{A}(0.957) \\
\mathrm{G}(0.043)\end{array}$ & 0.957 & 0.043 & 0.084 & 0.176 & 0.486 & $<0.01$ \\
\hline $1659(\mathrm{G} \rightarrow \mathrm{A})$ & $\begin{array}{l}\text { GG }(0.298) \\
\text { GA }(0.532) \\
\text { AA }(0.170)\end{array}$ & $\begin{array}{l}G(0.564) \\
A(0.436)\end{array}$ & 0.468 & 0.532 & 0.502 & 0.685 & -0.071 & 0.638 \\
\hline $1750(\mathrm{G} \rightarrow \mathrm{A})$ & $\begin{array}{l}\text { GG }(0.872) \\
\text { GA }(0.085) \\
\text { AA }(0.043)\end{array}$ & $\begin{array}{l}\mathrm{G}(0.915) \\
\mathrm{A}(0.085)\end{array}$ & 0.915 & 0.085 & 0.159 & 0.291 & 0.462 & $<0.01$ \\
\hline
\end{tabular}

*Frequency; $H_{\mathrm{O}}$, observed homozygosity; $H_{\mathrm{O}}$. observed heterozygosity; $H_{\mathrm{E}}$, expected heterozygosity; SI, Shannon index; $F_{\mathrm{IS}}$, inbreeding coefficient; P-HW, Hardy Weinberg probability.

At position 1643, the observed homozygosity $\left(\mathrm{Ho}_{\mathrm{ob}}\right)$ was very high $(0.957)$ and observed heterozygosity $\left(\mathrm{He}_{\mathrm{ob}}\right)$ very low (0.043), demonstrating significant deviations from HWE $(P<$ $0.01)$; genetic diversity of this SNP, on the basis of expected heterozygosity $\left(\mathrm{He}_{\text {exp }}\right)$ valuw and Shannon index (SI), was considered low (Table 1). At position 1659, restrained values of $\mathrm{Ho}_{\mathrm{ob}}$ (0.468) and $\mathrm{He}_{\mathrm{ob}}(0.532)$ indicated no deviations of HWE for the SNP $(P>0.05)$, and genetic 
diversity was considered to be moderate. At position 1750, $\mathrm{Ho}_{\mathrm{ob}}$ was high (0.915) and $\mathrm{He}$ ob low (0.085), demonstrating significant deviation from HWE $(P<0.01)$; genetic diversity of this SNP was considered low (Table 1). In general, when the whole flock was assessed considering all SNPS, HWE deviations were significant $(P<0.05)$.

\section{DISCUSSION}

Monteleone et al. (2009) reported three SNPs at positions 1659, 1750 and 1761 in exon II of $\beta$-defensin in Italian sheep, then an additional SNP position 1667 (Monteleone et al., 2011). In this study, we describe a new SNP at position 1643 in exon II of SBD-2. This SNP occurs in the 37 th codon, with the wild codon ATC encoding the aa isoleucine, and the mutant codon GTC encoding valine; both are hydrophobic aliphatic amino acids (Malkov et al., 2008).

Herve et al. (2014) observed that for chicken ovodefensins, structural alterations in $\beta$-defensin protein resulted in tri-dimensional modifications and changes to the antimicrobial spectrum, due to changes in polypeptide $\beta$-chains generating lower innate immune system efficiency. In our study, identified amino acid substitutions were predicted to be tolerable based on a SIFT analysis score less than or equal to 0.05 for deleterious changes, and greater than 0.05 for tolerated changes ( $\mathrm{Ng}$ e Henikoff, 2003). As such, our results corroborate those of Montelone et al. (2011), who determined that some of the mutations in SBD-2 resulted in aa substitutions but did not result in predicted alterations in polypeptide structure or function (scores $>0.05$ ). Using PANTHER analysis methods, it is estimated that a given variant will cause a deleterious effect on protein function when subPSEC scores of -3 correspond to a $\mathrm{P}_{\text {deleterious }}$ of 0.5 (Thomas et al., 2003). This finding corroborated those of Montelone et al. (2011) in a study of a population of dairy sheep from Valle del Bellice, Italy.

The polymorphism in position $1667(\mathrm{G} \rightarrow \mathrm{A})$ had a higher frequency of heterozygotes than homozygotes, consistent with the findings of Montelone et al. (2009 and 2011). However, the polymorphism in position $1750(\mathrm{G} \rightarrow \mathrm{A})$ had a higher frequency of $\mathrm{GG}$ homozygotes than the rest of the genotypes, differing from the findings of Montelone et al. (2009 and 2011), who observed higher heterozygous frequencies (above 0.5).

Considering the relevance of the antimicrobial activity of $\beta$-defensin 2 in modulating the immune system of sheep, it is of fundamental importance to assess polymorphisms of this gene in other herds and breeds reared in north Brazil, in order to associate polymorphisms with performance traits affected by the innate immune system.

\section{Conflicts of interest}

The authors declare no conflict of interest.

\section{ACKNOWLEDGMENTS}

We are very grateful for samples provided by Centro de Pesquisa de Caprinos e Ovinos do Pará, Universidade Federal Rural da Amazônia. We also extend our gratitude to the Laboratório de Tecnologia Biomolecular da Universidade Federal do Pará, for facilitating parts of the laboratory work, and to the Instituto de Pesquisa Evandro Chagas for assisting in DNA sequencing. 


\section{REFERENCES}

Bagnicka E, Strzałkowska N, Jóżwik A, Krzyżewski J, et al. (2010). Expression and polymorphism of defensins in farm animals. Acta Biochim. Pol. 4: 487-497.

Brogden KA, Ackermann M, McCray PB Jr and Tack BF (2003). Antimicrobial peptides in animals and their role in host defences. Int. J. Antimicrob. Agents 22: 465-478.

Casseb AR, Casseb LMN, da Silva SP and Vasconcelos PFC (2013). Arbovírus: importante zoonose na Amazônia Brasileira. Vet. Zootec. 20: 9-21.

Hall TA (1999). BioEdit: a user-friendly biological sequence alignment editor and analysis program for Windows 95/98/NT. Nucl. Acids Symp. Ser. 41: 95-98.

Hervé V, Meudal H, Labas V, Réhault-Godbert S, et al. (2014). Three-dimensional NMR structure of hen egg gallin (chicken ovodefensin) reveals a new variation of the $\beta$-defensin fold. J. Biol. Chem. 289: 7211-7220.

Huttner KM, Bresinski-Caliguri DJ, Mahoney MM and Diamond G (1998a). Antimicrobial peptide expression is developmentally regulated in the ovine gastrointenstinal tract. J. Nutr. 128: 297S-299S.

Huttner KM, Lambeth MR, Burkin HR, Burkin DJ, et al. (1998b). Localization and genomic organization of sheep antimicrobial peptide genes. Gene 206: 85-91.

IBGE - Instituto Brasileiro de Geografia e Estatística (2011). Produção da pecuária municipal, Rio de Janeiro, 39:1-63.

Kaiser V and Diamond G (2000). Expression of mammalian defensin genes. J. Leukoc. Biol. 68: 779-784.

Malkov SN, Živković MV, Beljanski MV, Hall MB, et al. (2008). A reexamination of the propensities of amino acids towards a particular secondary structure: classification of amino acids based on their chemical structure. J. Mol. Model. 14: 769-775.

Monteleone G, Calascibetta D, Reina R and Portolano B (2009). Study of $\beta$-defensin polymorphisms in Valle del Belice dairy sheep. Ital. J. Anim. Sci. 8: 111-113.

Monteleone G, Calascibetta D, Scaturro M, Galluzzo P, et al. (2011). Polymorphisms of $\beta$-defensin genes in Valle del Belice dairy sheep. Mol. Biol. Rep. 38: 5405-5412.

$\mathrm{Ng}$ PC and Henikoff S (2003). SIFT: predicting amino acid changes that affect protein function. Nucleic Acids Res. 31: 3812-3814.

Pereira RGA, Costa NL, Townsend CR and Magalhães JA (2008). Ovinos como componente dos sistemas produtivos amazônicos. EMBRAPA Comunicado Técnico 337. Porto Velho-RO, 1-4.

Raymond M and Rousset F (1995). GENEPOP (version 1.2) - population-genetics software for exact tests and ecumenicism. J. Hered. 86: 248-249.

Sambrook J, Fritsch EF and Maniatis T (1989). Molecular Cloning: a Laboratory Manual. 2nd edn. Cold Spring Harbor Laboratory Press, New York.

Selsted ME and Ouellette AJ (2005). Mammalian defensins in the antimicrobial immune response. Nat. Immunol. 6: 551-557.

Thomas PD, Campbell MJ, Kejariwal A, Mi H, et al. (2003). PANTHER: a library of protein families and subfamilies indexed by function. Genome Res. 13: 2129-2141.

Yeh FC, Yang RC and Boyle T (1999). POPGENE version 1.32: Microsoft Window-based freeware for population genetic analysis. University of Alberta, Edmonton. 